\title{
Development of a Unity in Diversity-based Pancasila Education Text Book for Indonesian Universities
}

\author{
Aim Abdulkarim \\ Prof., Universitas Pendidikan Indonesia, Indonesia, aimabdulkarim@upi.edu
}

\section{Kokom Komalasari}

Prof., Universitas Pendidikan Indonesia, Indonesia, kokom@upi.edu

\section{Didin Saripudin}

Prof., Universitas Pendidikan Indonesia, Indonesia, saripudinupi@yahoo.com

\author{
Neiny Ratmaningsih \\ Dr., Universitas Pendidikan Indonesia, Indonesia, neiny@upi.edu
}

\section{Diana Noor Anggraini}

Lecturer., Universitas Pendidikan Indonesia, Indonesia, diana.anggraini@upi.edu

This study aimed to develop a Pancasila education textbook model based on Indonesia's Bhinneka Tunggal Ika "Unity in Diversity" as teaching materials for compulsory subjects in Indonesian universities. The study used a Research and Development approach, where the data were collected through focused group discussions and questionnaires. While qualitative data were analyzed using an interactive analysis and quantitative data analysis used percentages. The research participants consisted of lecturers and students at nine universities in Indonesia. The findings reveal that 1) the conceptual model of the Unity in Diversity-based Pancasila education textbook is applicable and contextual which presents the latest issues in accordance with the issue of Indonesian diversity. This model integrates tolerance values in the diversity of religious, physical, social, cultural, linguistic, and ideological aspects; 2) The content of book constitutes the following components: chapter titles, introductions, keyword and concept map, material presentation and elaboration of Bhinneka Tunggal Ika values, competence performances, summaries, reflections, authentic assessments, feedback, and followup activities.

Keywords: textbook, unity in diversity, Pancasila education, higher education, learning

Citation: Abdulkarim, A., Komalasari, K., Saripudin, D., Ratmaningsih, N., \& Anggraini, D. N. (2020). Development of a Unity in Diversity-based Pancasila Education Text Book for Indonesian Universities. International Journal of Instruction, 13(1), 371-386. https://doi.org/10.29333/iji.2020.13125a 


\section{INTRODUCTION}

Indonesian society is ethnically, culturally and religiously a pluralistic society. Indonesian nationalism as a unification of ethnicity has a challenge, as various ethnic conflicts arise due to strong regionalism (Wiriaatmadja, 2004; Saripudin \& Komalasari, 2016). Entering this era of disruption, Indonesian is facing yet another challenge by the emergence of social conflicts that could threaten the nation's integration, including the proliferation of massive dissemination of hate speech through social media, increasing intolerance, and technological evolution targeting all walks of life (Indriyani \& Hermawan, 2018).

The basic framework of Indonesian life based on the Pancasila ideology (the five principles) holds that the diversity of ethnicities, religions, and races are the assets or wealth of the nation. Through Bhinneka Tunggal Ika, the concept of togetherness and ethnic unification will bring back the spirit of the Indonesian people to uphold unity in diversity. This principle was proposed after Indonesian independence by Indonesia's first President, Ir. Soekarno, that the beauty of pluralism is well reflected in his motto "Let jasmine, cananga, roses, chrysolite, and all flowers bloom together in Indonesian gardens" (Soekarno, 1964).

How is Pancasila in Indonesia able to accommodate the diversity that exists in society? The state's values contained in the Pancasila precepts are not solely conceptual, but are based on the cultural values of the Indonesian people (Kaelan, 2004: 13). One form of integration of Unity in Diversity in education is realized through the internalization of the values of Unity in Diversity in the implementation of Pancasila Education. The practice of such education must render all citizens as lifelong learners (Abdulkarim, et al., 2018). Philosophically, Pancasila education lays a solid foundation for the Indonesia's national education system. From this springs the essence of national education which can nurture and guide the development of educational theories and the practices based on the Pancasila ideology (Barnadib, 1994; Siswoyo, 2013).

One important component of an education curriculum is a textbook. A textbook should contain the basics of the subject matter and contribute to helping students understand the world in a real life (UNESCO 1970; Komalasari \& Saripudin, 2017). Textbooks also have implications for critical thinking skills, where readers can critically understand diversity issues (Abdulkarim, 2007). The development of the Unity in Diversity-based Pancasila Education textbook model was intended to strengthen a commitment as a pluralistic nation and reinforce the idea that Unity in Diversity, that represents the state's soul and character, must be ingrained in the life of the nation-state of Indonesia. This textbook is expected to raise the awareness of the values of Bhinneka Tunggal Ika, so that students have sensitivity in dealing with social symptoms and problems rooted in differences in ethnicities, races, religions, and values that occur in the community (Farisi, 2014; Awaru, 2016).

This textbook is based on educational philosophy of constructivism with contextual approach, so that the material and presentation of the textbook can construct students' 
understanding and awareness of unity in diversity through linking the material to the reality of Indonesian multicultural society.

The problem this research addressed in general was how to develop a Unity in Diversity-based Pancasila Education textbook for Indonesian Universities. In particular, the research problems were specifically formulated as follows:

1. What is the conceptual textbook model of Unity in Diversity-based Pancasila Education for Indonesian Universities?

2. How to develop a draft of Unity in Diversity-based Pancasila Education textbook for Indonesian Universities?

3. What are the results of the expert validation, limited and extensive trials on the textbook draft?

\section{METHOD}

This research was carried out using a Research and Development approach, as it is deemed a suitable model to "develop and validate educational products" (Borg and Gall, 2003). This research is also called 'research-based development', which serves as a strategy and aims to improve the quality and productivity of education by generating a product. In this research, the Research and Development approach was utilized to produce a Unity in Diversity-based Pancasila Education textbook for a higher education context.

\section{Process}

Borg and Gall's (2003) research and development framework was utilized, which consists of ten steps. In the context of this study, only step one to six were used namely:

1. Research and information collecting: Literature studies related to the issues studied, and preparation for formulating the research framework.

2. Planning: Formulate skills and expertise related to the making of Unity in Diversity-based Pancasila Education Text Book to determine the objectives to be achieved at each stage, and to conduct feasibility studies in a limited way.

3. Developing preliminary form of product: Develop the initial form of the product to be generated the initial product of Unity in Diversity-based Pancasila Education Text Book. Included in this step is the preparation of supporting components, preparing guidelines and manuals, and evaluating the feasibility of supporting tools.

4. Preliminary field testing: Requests input from experts and practitioners, and conducts initial product piloting of Unity in Diversity-based Pancasila Education Text Book on a limited scale.

5. Main product revision: Make improvements to the initial products of Unity in Diversity-based Pancasila Education Text Book that has been produced.

6. Main field testing: Create Unity in Diversity-based Pancasila Education Text Book and perform expert validation. 


\section{Participants}

The research was conducted in Indonesia in a higher education setting. The population in this study were college students in Indonesia who took a Pancasila Education course in the 2017/2018 academic year. The sampling technique was purposive. The research samples and research locations in the limited trial included Indonesia University of Education, Bandung Institute of Technology, and Bandung State Polytechnic. As for the extensive trial, the samples covered Telkom Bandung University, Sultan Ageng Tirtayasa University, Jakarta State University, Tulung Agung College of Teacher Training and Pedagogy, Ahmad Dahlan University, and Palangkaraya University. The expert groups that have been involved in the Focus Group Discussion are textbook experts, Pancasila material experts, value learning experts, and lecturers in Pancasila Education courses.

\section{Data Collection Tools}

Measuring tools used were interview sheets and questioners. The interview sheets were used to collect data on the needs analysis and preparation of the textbook model, while the questionnaires to validate the model by content material experts and book experts, and by students to gauge the effectiveness and worth of the textbook. The interview sheets contains open-ended questions that must be answered by participant. The questionnaires contains statements that must be assessed by participants using the scale of "very good, good, poor, and very poor". The questionnaires were tested for validity with Pearson's product-moment correlation and reliability tested with Cronbach's alpha (Shadish, et.al, 2002). Based on the test, instruments of questioner were valid with coefficient of correlation bigger than 0.418 ( $\mathrm{r}$ table) and have coefficient of alpha reliability $0.786>0.600$ indicates the instrumen is reliable.

The research instruments used were focus group discussion (FGD) guidelines and questionnaires. The guidelines were used to collect data on the needs analysis and preparation of the textbook model, while the questionnaires to validate the model by content material experts and book experts, and by students to gauge the effectiveness and worth of the textbook.

\section{Data analysis}

Qualitative data were analyzed through: (1) conducting data reduction by summarizing field reports; (2) systematically arranging the data according to certain categories and classifications; (3) making display of data in the form of tables or images so that the relationship between the data becomes clear and intact; (4) conducting a cross site analysis by comparing and analyzing the data in depth; and (5) presenting the findings, drawing conclusions in the form of general trends and implications for their application, and recommendations for development (Fraenkel \& Wallen, 2008). Furthermore, quantitative analysis was performed in the form of percentages, diagrams, and basic competency mapping patterns (Creswell: 2012). 


\section{FINDINGS}

\section{The Conceptual model of Unity in Deiversity-based Pancasila education textbook for higher education in Indonesia}

Book development was undertaken through curriculum analysis, book needs analysis and content analysis. Analysis of the needs of the Pancasila Education textbook reveals that the students need a book that, among others: 1) is applicative/contextual; 2) contains the latest issues in accordance with Unity in Diversity; and 3) is supported by recent references. The three basic needs according to the students serve as a baseline for developing an appropriate textbook model. Needs identification strategy of the book can be seen in Figure 1.

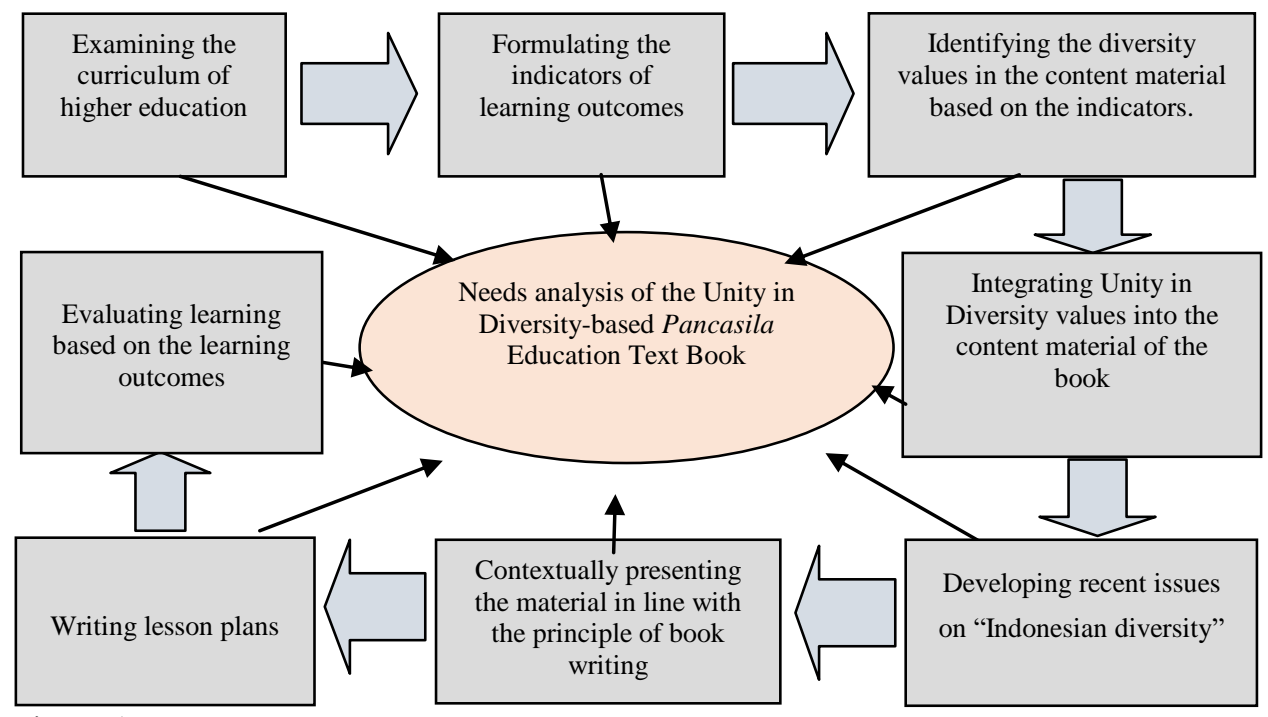

Figure 1

Needs analysis of the textbook

Based on the needs analysis, a conceptual Pancasila Education textbook model based on Unity in Diversity that incorporates the values "unity in diversity" in physical, ethnic, religious, cultural, political and ideological differences in the content material according to the curriculum set by the government by taking into account the contextual and applicative principles, and meeting the requirements of a good book was formulated. Based on such a conceptual model, the textbook was designed with the following outline:

1. Book Identity, including:

a. cover: the title and authors of the book;

b. preface: foreword on the general contents of the book; 
c. how to use the book: a brief guide on how to read the book, so as to provide optimal understanding of facts, principles, procedures, values of diversity and reflections;

d. table of contents: an outline of the textbook.

2. Book contents, including:

a. Titles of the chapters were made meaningful (reflecting the material and values of diversity)

b. Introduction begins with a presentation of pictures, stories, poems, cases, etc., followed by an apperception of the material and reflection on the values of diversity to be fostered.

c. Keyword and concept map is a general description of all the materials to be presented and life values to be developed in each chapter.

d. Content materials and elaboration of values of diversity include facts, concepts, principles, procedures, and values of diversity (attitudes). The following is an overview of the content materials to be presented.

1) Facts: names, when, what, and where;

2) Concepts: defining, identifying, classifying, mentioning characteristics;

3) Principles: understanding and Application of a theory, law, or formula, hypothesis, relationships between variables;

4) Procedures: making a flowchart, sequential steps;

5) Unity in Diversity values: the spirit of tolerance to religious, physical, cultural, linguistic, political and ideological differences.

e. Competence performance;

f. Summaries contain the conclusions of the learning material to be mastered and the values of diversity to be developed;

g. Reflections contain pondering on the values of diversity to be practiced in everyday life;

h. Authentic assessments contain a series of assessment instruments (tests, attitude scales, and performances);

i. Feedback contains answer keys and formats of assessment accompanied by assessment rubrics;

j. Follow-up activities (transfer, enrichment, remedial) contain recommendations for material enrichment activities for those who have achieved the expected competencies and remedial for those who have not.

3. End of the Book, including:

a. Glossary is a list of key concepts that often appear in the text and require explanation;

b. Bibliography is a collection of sources referred to in the book chapters.

\section{The Draft of Unity in Diversity-based Pancasila Education Textbook}

Bhinneka Tunggal Ika or Unity in Diversity is a concept that concerns not only tolerance of religious differences but also that of physical, cultural, linguistic, political and ideological differences (Farisi, 2014). The integration of Bhinneka Tunggal Ika in the Pancasila Education textbook material can be described as follows. 


\section{Religious tolerance in "Unity in Diversity"}

The spirit of religious tolerance is depicted in the textbook in the chapter "Pancasila in the Historical Context of the Struggle of the Indonesian Nation". At the time of the Majapahit Kingdom, it was shown how Hinduism (the Buddha) and Buddhism (Siva) coalesced in the Old Javanese world. This reflects the reality of Indonesia in the context of the relationship between Balinese Hinduism as a minority religion and Islam as the majority religion (Van der Meij, 2011; Santoso, 1975). While Indonesia is home to the largest number of Muslims in the world, its constitution guarantees religious rights for all. At least six world religions find adherents in Indonesia: Islam, Catholicism, Protestantism, Hinduism, Buddhism and Confucianism.

The textbook provides an illustration of Unity in Diversity in the diversity of religions (unity principle): "The God principle! Not only do the Indonesian nation worships God, but each Indonesian should also worship God, their own God. Christians worship God according to the teachings of Jesus Christ; Muslims do the same according to the teachings of the Prophet Muhammad, the Buddhist people pray according to the books they believe. The basic principle of service is that you cannot have two masters, only one master, namely God Almighty. That is the core mission of religious messenggers, i.e. to invite people to serve one master, namely God Almighty (Deuteronomy 6: 4-5, Matthew 6:24, Luke 16:13, Quran Chapter: Al Mu'minun [ 23]: 23 \& 32) (Mulyantoro, 2012; Zoelva, 2012).

\section{Tolerance in physical forms in "Unity in Diversity"}

The textbook in the chapter "Pancasila as a Philosophical System" enumerates the elements of Pancasila ingrained in the cultures, customs, religions and beliefs that have long been embraced by the people of Indonesia. The physical evidence of Bhinneka Tunggal Ika is apparent in architectural arts in places of worship such as mosques, churches, viharas, pagodas, and (Hindu and Buddha) temples. These buildings have been around for a long time and utilized by Indonesian people for various activities such as worship, deliberation and other social activities. Hindu architecture has also long inspired mosques, palaces and graves in terms of physical designs. Indonesian Islamic architecture is peculiar and cannot be separated from syncretism, as is dominant in Islamic buildings on the coast of Java. Acculturation has become the primary feature of the architecture of Islamic mosques in Indonesia. This is made possible because "Islam is a democratic religion, and does not recognize social differences and personal degrees" (Ali, 2011; Pijper, 1984; Suranti \& Saptriarso, 2009).

\section{Tolerance in cultural diversity in "Unity in Diversity"}

The textbook also provides a pedagogical guide to the importance of respecting differences, so that conflicts between ethnic groups owing to differences in their culture can be avoided. Regional cultures in Indonesia have been used as an identity and even a strong bond in building a nation. There are around 500 tribes in Indonesia that spread from Sabang (northwesternmost) to Merauke (southeasternmost). Among others are Aceh, Gayo, Batak, Malay, Minangkabauan, Jambi, Palembang (the Sumatra Island), Betawi, Javanese, Sundanese, Madurese (the Java Island), Balinese (the Bali Island), 
Sasak (the Lombok Island), Flores and Timor ethnic groups (East and West Nusa Tenggara Islands), Dayak, Banjar, Melayu tribes (Kalimantan), Minahasa, Toraja, Bugis, Makassar, Mandar (Sulawesi), Asmat, Marind-anim, Dani, Yali, Korowai, Biak, Serui, and Artak (Papua).

Pancasila as a cultural identity can be traced from the prevailing religious life in Indonesian society. The traditions and cultures of the Indonesian people can be seen from the vital role of major religions have played, such as: Hindu, Buddhist, Islamic, and Christian civilizations. These religions have contributed to the establishment of values, norms, traditions, and habits that floursih in society. For example, the establishment of the traditions and cultures of Malay, Minangkabau, and Acehnese cannot be separated from the role of Islamic civilization. Meanwhile, Toraja and Papuan cultures are inseparable from Christian civilization. Similarly, the cultural establishment of Balinese society has fully shaped by Hindu civilization (Ali, 2009).

Tolerance in linguistic diversity in "Unity in Diversity"

There are more than 700 languages and dialects used in Indonesia, which are spoken by various ethnic groups such as Acehnese, Batak, Sundanese, Javanese, Sasak, Tetum Timor, Dayak, Minahasa, Toraja, Bugis, Halmahera, Ambon, Seram, and a number of Papuan languages. Indonesian then serves as a national language. Indonesian language is similar to Malay and written in the Roman script based on European orthography. English is the most common foreign language, while Arabic, Chinese, Japanese, German and French are increasingly popular.

In the second Indonesian Youth Congress on October 28, 1928, Indonesian language was first declared a lingua franca for all ethnic groups living in what is now Indonesia. The Youth Oath event is the starting point for all groups to work together to build one motherland, one nation, and one national language, Indonesia. This was also one of the crucial events before independence because it encouraged Indonesians to immediately fight and attain their independence from the colonialists (the Netherlands and Japan).

Tolerance in political diversity in "Unity in Diversity"

This textbook also presents various educational, political, social, and economic organizations established during the struggle against the Dutch colonialism in the twentieth century. These organizations include: Budi Oetomo, Sarekat Islam, Indische Partij, Perhimpunan Indonesia (PI), and the Indonesian Communist Party (PKI). At first, regional organizations such as Jong Sumatranen Bond, Pasundan Circle of Friends, Jong Minahasa, Jong Ambon, Jong Celebes (Sulawesi), Jong Batak, and other youth organizations, and religious associations, such as Jong Islamieten Bond, Anshor Nahdatul Ulama, Muhammadiyah Youth, Christian Youth Association and Catholic Youth Association were abound. Although regional in nature, all of them had the same aspirations, namely to advance the Indonesian Nation and were willing to be coalesced with various other more integrative, bigger movements or organizations.

To unite Indonesian youth, a congress was held on April 30 to May 2, 1926 in Jakarta. The aim of the First Youth Congress was to establish a national youth association. It was 
agreed the establishment of a permanent organization for the needs of Indonesian Unity was a necessity. Then, with increasingly stronger aspirations to claim independence, in the second Youth Congress, a pledge or promise called the Oath of Youth emerged. The oath of youth was the oath of loyalty and promise of the youth to bolster the determination and the spirit of the Indonesian people and foster awareness for all the people of Indonesia in safeguarding the unity of the nation.

Tolerance in ideological diveristy in "Unity in Diversity"

The diversed ideologies in the national movement is also represented in the textbook in the chapter "Pancasila as the Ideology of the State". Major ideologies that penetrated Indonesia through the Western education system include liberalism, socialism, communism and capitalism. Such diversities are bound by the spirit and ideals of Indonesia in maintaining the ideology of the Pancasila. The values from external ideologies in this global world may conflict with the values of the Pancasila, which presents challenges.

Pancasila fulfills the prerequisites of being an open ideology because it is rooted in the national outlook and philosophy of the nation. However, even though Pancasila is open, it does not mean that its openness can ruin or negate the identity of Pancasila itself. Such openness entails that Pancasila is always able to interact dynamically. The values will remain unchanged, but their implementation is adapted to the real needs and challenges facing the people. This suggest that Pancasila is actual, dynamic, anticipatory and always able to adjust to the times, science and technology development and the dynamics of people's aspirations.

\section{The Results of Experts Validation}

Based on the results of validation of four experts (a curriculum expert, an expert on Pancasila Education and Citizenship Education, a linguist, and a graphics expert), the following obtains. 
Table 1

The results of experts validation on the textbook

\begin{tabular}{|c|c|c|c|c|c|c|}
\hline \multirow[t]{2}{*}{ No } & \multirow{2}{*}{$\begin{array}{l}\text { Assessed } \\
\text { component }\end{array}$} & \multirow[t]{2}{*}{ Assessed aspect } & \multicolumn{4}{|c|}{ Results $(\mathrm{N}=4)$} \\
\hline & & & $\begin{array}{l}\text { Very good } \\
(\%)\end{array}$ & $\begin{array}{l}\text { Good } \\
(\%)\end{array}$ & $\begin{array}{l}\text { Poor } \\
(\%)\end{array}$ & $\begin{array}{l}\text { Very Poor } \\
(\%)\end{array}$ \\
\hline \multirow[t]{5}{*}{ A. } & \multirow{5}{*}{$\begin{array}{l}\text { Alignment of the } \\
\text { book with the } \\
\text { curriculum }\end{array}$} & $\begin{array}{l}\text { The material fits the target of the } \\
\text { University curriculum }\end{array}$ & 70 & 15 & 15 & 0 \\
\hline & & $\begin{array}{l}\text { The material fits the curriculum target for } \\
\text { each semester }\end{array}$ & 65 & 25 & 10 & 0 \\
\hline & & $\begin{array}{l}\text { The contents comprise project-based } \\
\text { tasks }\end{array}$ & 50 & 30 & 10 & 10 \\
\hline & & $\begin{array}{l}\text { The contents comprise a scientific } \\
\text { integrative approach }\end{array}$ & 70 & 20 & 5 & 5 \\
\hline & & $\begin{array}{l}\text { All contents are developed on the basis } \\
\text { of brainstorming }\end{array}$ & 60 & 20 & 15 & 5 \\
\hline \multicolumn{3}{|c|}{ Mean Scores of Component A } & 63 & 22 & 11 & 4 \\
\hline \multirow[t]{5}{*}{ B } & \multirow[t]{5}{*}{ Presentation } & $\begin{array}{l}\text { The material is presented based on the } \\
\text { stages of learning }\end{array}$ & 68 & 12 & 10 & 10 \\
\hline & & $\begin{array}{l}\text { The material is presented in an } \\
\text { interesting manner }\end{array}$ & 70 & 16 & 5 & 9 \\
\hline & & $\begin{array}{l}\text { The material presented easily } \\
\text { understandable by the reader }\end{array}$ & 60 & 10 & 20 & 10 \\
\hline & & $\begin{array}{l}\text { The material presented is able to engage } \\
\text { student participation }\end{array}$ & 65 & 20 & 10 & 5 \\
\hline & & $\begin{array}{l}\text { The material presented is related to sub- } \\
\text { sections, questions and exercises }\end{array}$ & 58 & 20 & 20 & 2 \\
\hline \multicolumn{3}{|c|}{ Mean Scores of Component B } & 64.2 & 15,6 & 13 & 7.2 \\
\hline \multirow[t]{5}{*}{ C. } & \multirow[t]{5}{*}{ Graphics } & Use of standardized formats & 72 & 10 & 10 & 8 \\
\hline & & $\begin{array}{l}\text { Attractive, simple and illustrative cover } \\
\text { design }\end{array}$ & 62 & 10 & 20 & 8 \\
\hline & & $\begin{array}{l}\text { Content design is easy to read and } \\
\text { supports book material. }\end{array}$ & 50 & 20 & 15 & 15 \\
\hline & & Clear and contrasting color combination & 40 & 15 & 30 & 15 \\
\hline & & Neat font shape according to layout & 40 & 20 & 25 & 15 \\
\hline \multicolumn{3}{|c|}{ Mean Scores of Component C } & 52.8 & 15 & 20 & 12.2 \\
\hline \multirow[t]{5}{*}{ D. } & \multirow[t]{5}{*}{$\begin{array}{l}\text { The values of } \\
\text { Unity in Diversity }\end{array}$} & $\begin{array}{l}\text { Material is based on the value of the } \\
\text { unity, interests and safety of the state and } \\
\text { nation above interests }\end{array}$ & 74 & 10 & 10 & 6 \\
\hline & & $\begin{array}{l}\text { The material is based on the value of } \\
\text { willingness to sacrifice for the sake of the } \\
\text { state and nation }\end{array}$ & 65 & 15 & 10 & 10 \\
\hline & & $\begin{array}{l}\text { Material fosters the love of the country } \\
\text { and its people. }\end{array}$ & 68 & 15 & 15 & 2 \\
\hline & & $\begin{array}{l}\text { The material fosters pride in being an } \\
\text { Indonesian }\end{array}$ & 62 & 25 & 5 & 8 \\
\hline & & $\begin{array}{l}\text { Material is able to build communication } \\
\text { for the sake of unity }\end{array}$ & 55 & 20 & 15 & 10 \\
\hline \multicolumn{3}{|c|}{ Mean Scores of Component D } & 64.8 & 17 & 11 & 7.2 \\
\hline \multicolumn{3}{|c|}{ Total } & 61.2 & 17.4 & 13.75 & 7.65 \\
\hline
\end{tabular}

The results of the validation of the completeness of the book components show that most components of the curriculum, presentation, graphics and values of Unity in Diversity are considered quite good. The curriculum aspect obtains the average value of $63 \%$ (excellent), the presentation aspect receives $64.2 \%$ (excellent), graphics $52.8 \%$ (excellent), and aspects of values have an average of $64.8 \%$ (excellent). What needs to be improved in graphics is the design of the content, the combination of colors and font shapes that fit the layout.

International Journal of Instruction, January $2020 \bullet$ Vol.13, No.1 


\section{The students' assessment on the effectiveness and usability of the textbook}

The degree of effectiveness and usability of the textbook under study in the Pancasila Education course was derived from the results of limited trials and extensive trials from twelve universities in Indonesia. What follows is the effectiveness and usability of the textbook in a number of randomly chosen study programs.

Table 2

Student assessment on effectiveness and usability of the book

\begin{tabular}{|c|c|c|c|c|c|c|}
\hline \multirow[t]{2}{*}{ No } & \multirow[t]{2}{*}{ Assessed Component } & \multirow[t]{2}{*}{ Assessed Aspect } & \multicolumn{4}{|c|}{ Results $(\mathrm{N}=520)$} \\
\hline & & & $\begin{array}{l}\text { Very good } \\
(\%)\end{array}$ & $\begin{array}{c}\text { Good } \\
(\%)\end{array}$ & $\begin{array}{l}\text { Poor } \\
(\%)\end{array}$ & $\begin{array}{c}\text { Very } \\
\text { Poor } \\
(\%)\end{array}$ \\
\hline \multirow[t]{6}{*}{ A } & \multirow[t]{5}{*}{ Book feasibility } & Concepts & 56.5 & 15.5 & 18 & 10 \\
\hline & & Relevance & 45.6 & 20.4 & 20 & 14 \\
\hline & & Language use & 66.2 & 20.5 & 10.3 & 3 \\
\hline & & Presentation & 50.5 & 20 & 19.5 & 10 \\
\hline & & Graphics & 35.3 & 23.7 & 20 & 21 \\
\hline & \multicolumn{2}{|c|}{ Mean scores of Component A } & 50.82 & 20.02 & 17.56 & 11.6 \\
\hline \multirow[t]{7}{*}{ B } & \multirow{5}{*}{$\begin{array}{l}\text { The values of } \\
\text { Unity in Diversity }\end{array}$} & Willingness to unite & 72.8 & 15.2 & 10 & 2 \\
\hline & & Willingness to sacrifice & 66.8 & 14 & 10.2 & 9 \\
\hline & & Love of homeland & 55.5 & 25 & 12.5 & 7 \\
\hline & & $\begin{array}{l}\text { Pride to be an } \\
\text { Indonesian }\end{array}$ & 54.3 & 24.4 & 11 & 10.3 \\
\hline & & $\begin{array}{l}\text { Intercultural } \\
\text { communication }\end{array}$ & 48.2 & 12.8 & 20 & 19 \\
\hline & \multicolumn{2}{|c|}{ Mean scores of Component B } & 59.52 & 18.28 & 12.74 & 9.46 \\
\hline & & Total scores & 55.17 & 19.24 & 15.15 & 10.53 \\
\hline
\end{tabular}

Analysis on a survey of the textbook in terms of the effectiveness and usability of the book reveals that most of the students consider the book to be worthy of use. The book feasibility is classified as excellent at $50.82 \%$ and the integration of Unity in Diversity values is likewise excellent at $59.52 \%$. The areas that need to be improved in the components of the book are graphics and material relevance. In regards to the integration of Unity in Diversity value, what to be improved is material that caters to nationalism and intercultural communication.

\section{DISCUSSION}

The above-mentioned findings can be accounted for using various theories and views as follows:

First, the development of the proposed textbook constituted three stages, namely analysis, design and development. The book was composed of: 1) book identity: cover, 
preface, how to use the book, and table of contents; 2) book contents: chapter titles, introductions, keyword and concept map, material presentation and elaboration of values (facts, concepts, principles, procedures, values of Unity in Diversity), competence performances, summaries, reflections, authentic assessments, feedback, and follow up activities (transfer, enrichment, remedial); 3) end of the book: glossary and bibliography. These stages of developing the textbook as outlined above are in accordance with the principle: a) meaningfulness, the book is meaningful to students; b) success, we can measure how the book may influence student behavior; c) balance, the book may develop students' personality in a balanced and comprehensive manner; and d) practicality, the book addresses daily actions (Harjanto, 2008; Komalasari \& Saripudin, 2018).

The development of content materials in the book is in line with the notion of constructivism that one's knowledge is one's own construction (Glasersfeld, 1989). Students form schemes, categories, concepts, and knowledge structures needed to embrace global insight. This takes into account the following elements: 1) analyzing learning outcomes in the curriculum; 2) choosing concepts, facts, principles, and procedures on the basis of learning outcomes; 3) assessing the appropriateness of the contents of the book in terms of achieving the objectives of the course (students' cognitive, affective, psychomotor domains), and applying the general principles of textbook writing; 4) assessing the feasibility of presenting books by contextually integrating learning design principles; 5) exploring material from the daily life environment of students, including social culture, economy, and student environment, and 6) developing values of Bhinneka Tunggal Ika, namely unity, willing to sacrifice, love for the motherland, pride of being part of Indonesia; and developing intercultural communication. The values of Unity in Diversity are also reflected in several concepts such as intermingling, acculturation, syncretism, unity and nationalism (Anggraini, 2017; Utami \& Widiadi, 2016).

The content of Bhinneka Tunggal Ika material is conceptualized, internalized, and actualized in Pancasila values. Unity in Diversity is explicitly portrayed in the harmony of unity and pluralism which reflects the reality of the Indonesian nation. Diversity in all aspects of life is not described as a threat to the unity of the Indonesian nation, but it is expected to be able to act as a source of wealth for the Indonesian nation throughout its history (Hardono, 1994). The principle of Unity in Diversity is in line with the elaboration of the five basic principles of Pancasila that will guide the development of the Indonesian nation. These five principles specifically are as follows: 1) Placing the unity, unity, interests and safety of the nation and state above personal or group interests; 2) Willingness to sacrifice for the benefit of the state and nation; 3) Love the homeland and the Indonesian people; 4) Proud to be Indonesian and live in Indonesia, and 5) Promote communication for the unity and unity of a nation that is united in diversity (Fitch, 2011).

Second, the results of expert validation relating to the quality of the textbook indicate that most components of curriculum relevance, presentation, graphics and the values of Unity in Diversity have been considered decent. This is so as the authors carefully heed 
the rules of writing a textbook including: 1) academically and scientifically accountable factual contents; 2) logical and systematic explanation; 3) presentation and rhetoric (the naration must be age appropriate in accordance with the theoretical basis of developmental psychology of the level of abstract thinking of students in higher education; 4) introduction of concepts using a "spiral" approach, starting from more complex and relatively abstract concepts; 5) informative and attractive settings and layouts of illustrations, images, and photos (Sjamsuddin, 2004). Based on the scope or the curriculum content, on the basis of the interview, the textbook has not shown a proportional scope; some lecturers view that the book in questio has not fully covered all the contents of the curriculum. Regarding the order of curriculum contents, it can be seen that the order of the subject headings and sub-headings is sequential (systematic). However, the contents of each sub-topic, aside from showing no relevance, also do not yet have a clear pattern and sequence (an inductive or deductive pattern).

Third, most of the students assessed the components of the textbook in question from the feasibility of books and the values of Bhinneka Tunggal Ika feasible. This aligns with the principle of book writing that dictates an interesting and communicative textbook so as to encourage students to read. It is believed that interactional patterns between lecturers and students can be fostered through textbooks. In textbooks, a value learning method involving lecturers and students can be explored to obtain meaningful learning (Komalasari \& Sapriya, 2016; Tarigan, 1986). One of the chief objectives of this Pancasila Education textbook is to promote the sustainability of Pancasila values as the nation's characters and as a bridge between the previous generation and the next generation. The nation's characters will translate to individuals' specific traits, such honesty, patience, humbleness, discipline, responsible, self-respect, creativity, cooperativeness, visionary-mindedness, nationalism, integrity, and sincerity in doing good deeds. These are in line with the understanding of values espoused by the teachings of Pancasila which include the principles of Godliness (religion), just and civilized humanity (humanism), the unity of Indonesia (nationality), the principle of democracy guided by inner wisdom and representativeness (democracy), and social justice for all Indonesian people (justice) in organic, harmonious, dynamic unity (Notonagoro, 1980; Soedjatmoko, 1991; Siswoyo, 2013).

\section{CONCLUSION}

The development of the Unity in Diversity-based Pancasila Education textbook encompassed three stages, namely the analysis stage, the design stage and the development stage. The textbook framework included: 1) book identity, including: cover, preface, and table of contents; 2) book contents, including: chapter titles, introductions, keyword and concept map, presentation of conent material and elaboration of values of diversity, competence performances, summaries, reflections, authentic assessments, feedback, and follow-up activities (transfer, enrichment, remedial); 3 ) end of the book, including: glossary and bibliography. The textbook model incorporated a concept that concerns tolerance of religious, physical, cultural, linguistic, political and ideological diversity. The results of expert validation demonstrate that most components of the curriculum, presentation, and graphics were deemed good. According 
to the students, the feasibility of books and the values of Unity in Diversity were assessed decent that the book was assumed to be able to raise awareness of diversity among students.

Based on these conclusions, suggestion is given as follows: The author of the Pancasila Education textbooks should integrate the values of unity in diversity in the textbook material and presentation. Pancasila Education Lecturers should use Pancasila textbooks through various creative and innovative learning models. Students must be able to develop higher-order thinking skills and multiculturalism in utilizing textbooks as learning resources

\section{Acknowledgments}

The research is a grant from the Ministry of Research, Technology, and Higher Education of Indonesia through the scheme of Excellent Higher Education Applied Research. The author would like to express sincere appreciation for all support provided.

\section{REFERENCES}

Abdulkarim, A., Ratmaningsih, N., \& Anggraini, D. N. (2018). Developing Civicpedia as a Civic Education E-Learning Media To Improve Students' Information Literacy. Journal of Social Studies Education Research, 9(3), 45-61.

Abdulkarim, A. (2007). Analisis Isi Buku Teks dan Implikasinya dalam Memberdayakan Keterampilan Berfikir Peserta didik SMA. In Jurnal Forum Kependidikan (Vol. 26, No. 2, pp. 71-80).

Ali, A. S. (2009). Negara Pancasila Jalan Kemaslahatan Berbangsa. Jakarta: Pustaka LP3ES.

Ali, M. (2011). Muslim Diversity: Islam and Local Tradition in Java and Sulawesi, Indonesia. Indonesian Journal of Islam and Muslim Societies, 1(1): 1-35.

Anggraini, D. N. (2017). Kontribusi Model Education Sustainable Development dalam Pembelajaran PKn Terhadap Kompetensi Kewarganegaraan. Prosiding Konferensi Nasional Kewarganegaraan III, Universitas Ahmad Dahlan, Yogyakarta, 11 November 2017, pp. 134-141.

Awaru, A.O.T. (2016). Membangun Karakter Bangsa Melalui Pendidikan Berbasis Multikultural di Sekolah, dalam Seminar Nasional "Pendidikan Ilmu-Ilmu Sosial Membentuk Karakter Bangsa Dalam Rangka Daya Saing Global”, Kerjasama: Fakultas Ilmu Sosial Universitas Negeri Makasar dan Himpunan Sarjana Pendidikan Ilmu-Ilmu Sosial Indonesia, Grand Clarion Hotel, Makasar, 29 Oktober 2016.

Barnadib, I. (1994). Educational philosophy: system and method (Filsafat pendidikan: sistem dan Kaedah). Yogyakarta: Penerbit Andi Offset.

Borg, W. R.,and Gall, M.D. (2003). Educational Research: An Introduction ( $\left.7^{\text {th }} \mathrm{ed}\right)$. New York: Longman, Inc. 
Creswell, J.W. (2012). Educational Research: Planning, Conducting, And Evaluating Quantitative And Qualitative Research. Boston: Pearson Education, Inc.

Farisi, M. I. (2014). Bhinneka Tunggal Ika [Unity in Diversity]: From Dynastic Policy to Classroom Practice. JSSE-Journal of Social Science Education. Volume 13 No. 1, 46-61, DOI 10.2390/jsse-v13-i1-1261

Fitch, R. M. (2011). Moral Education in Indonesia: a preliminary study. Educación y ciencia (ISSN 2448-525X), 1(1).

Fraenkel, J.R dan Wallen, N.E. (2008). How to Design and Evaluate Research in Education. New York : McGraw-Hill.

Glasersfeld, E. (1989). Knowing without Metaphysics: Aspects of the Radical Construktivist Position. In F. Steir (Ed), Research and Reflexivity: Toward a Cybernetic/Social Constructivist Way of Knowing. London: Sage.

Hardono, H. P. (1994). Hakikat dan Muatan Filsafat Pancasila, Yogyakarta: Kanisius.

Harjanto. (2008). Perencanaan Pengajaran. Jakarta: PT Rineka Cipta.

Indriyani, D., \& Hermawan, I. C. (2018). Evitalisasi Pancasila Sebagai Modal Integrasi Bangsa Di Era Disrupsi. In Seminar Nasional PKn UNNES (Vol. 2, No. 1, pp. 62-73).

Kaelan. (2004). Pendidikan Pancasila. Yogyakarta: Paradigma.

Komalasari, K \& Sapriya. (2016). Living Values Education in Teaching Materials to Develop Students' Civic Disposition, The New Educational Review, 44 (2), 107-124. DOI: 10.15804/tner.2016.44. 2.09.

Komalasari, K \& Saripudin, D. (2018). The Influence of Living Values EducationBased Civic Education Textbook on Student's Character Formation, International Journal of Instruction, 11 (1), 395-410.

Komalasari \& Saripudin. (2017). A Model of Living Values Education-based Civic Education Textbooks in Indonesia. The New Educational Review, Vol. 47, No. 1, Tahun 2017.

Mulyantoro, H. (2012). "Quantum Leap Pancasila, Membangun Peradaban Bangsa dengan Karakter Tuhan Yang Maha Esa”, Makalah pada Kongres Pancasila IV di UGM Yogyakarta tanggal 31 Mei-1 Juni 2012.

Notonagoro. (1980). Pancasila secara Ilmiah Populer, Cetakan ke-5. Jakarta: CV. Pantjuran Tujuh.

Pijper. (1984). Beberapa Studi tentang Sejarah Islam di Indonesia 1900-1950. Jakarta: Universitas Indonesia Press.

Saripudin, D \& Komalasari (2016). The Development of Multiculturalism Values in Indonesian History Textbook, American Journal of Applied Sciences, Vol 13, Issue 6, Tahun 2016. 
Santoso, S. (1975). Sutasoma: A Study in Old Javanese Wajrayana. New Delhi: International Academy of Indian Culture. Śatapitaka, Indo-Asian Literatures 213.

Shadish, W. R., Cook, T. D. \& Campbell, D. T. (2002). Experimental and QuasiExperimental Design for Generalized Causal Inference. Boston: Houghton Mifflin Company.

Siswoyo, D. (2013). Philosophy of education in Indonesia: Theory and thoughts of institutionalized state (PANCASILA). Asian Social Science, 9(12), 136.

Sjamsuddin, H. (2004). "Penulisan Buku Teks Sejarah: Kriteria dan Permasalahannya", dalam Historia, Jurnal Pendidikan Sejarah, Nomor 1. Vol. 1 Hal 12.

Soedjatmoko. (1991). Soedjatmoko and future concerns (Soedjatmoko dan keprihatinan masa depan). Yogyakarta: PT. Tiara Wacana.

Soekarno. (1964). Identify Pancasila: Pancasila State philosophy policy. Jakarta: Ministry of Information RI. (Camkan Pancasila: Pancasila dasar falsafah Negara. Jakarta: Departemen Penerangan RI.)

Suranti, \& Saptriarso, E.S. (2009). Ilmu Pengetahuan Sosial 4 untuk Sekolah Dasar dan Madrasah Ibtidaiyah Kelas IV. Jakarta: Pusat Perbukuan Depdiknas.

Utami, I. W. P., dan Widiadi, A. N. (2016). Wacana Bhineka Tunggal Ika dalam Buku Teks Sejarah. Paramita: Historical Studies Journal, 26(1), 106- 117.

UNESCO. (1970). Preparing Textbook Manuscripts. Paris: UNESCO.

Tarigan, H.G. (1986). Telaah Buku Teks Bahasa Indonesia. Bandung: Angkasa.

Van der Meij, D. (2011). Kakawin Sutasoma and Kakawin Nāgara Kṛtāgama. Bijdragen tot de Taal, Landen Volkenkunde, 167(2-3): 322-332.

Wiriatmadja, R. (2004). "Multicultural Perspective in Teaching History in the Chinese Indonesian Student”. Historia: Jurnal Pendidikan Sejarah, Vol. V, No. 9, Hal 62-75.

Zoelva, Hamdan. (2012). "Pelembagaan Nilai-nilai Pancasila dalam Perspektif Kehidupan Beragama, Sosial dan Budaya Melalui Putusan MK”, Makalah yang disajikan pada Kongres Pancasia IV di UGM Yogyakarta pada tanggal 31 Mei - 1 Juni 2012. 